\title{
Data Resource Profile: thousands of circulating RNA profiles of pre-clinical samples from the Janus Serum Bank Cohort
}

Hilde Langseth*1,2, Sinan Ugur Umu ${ }^{1}$ Cecilie Bucher-Johannessen ${ }^{1}$, Ronnie Babigumira ${ }^{1}$, Magnus Leithaug ${ }^{3}$, Marianne Lauritzen ${ }^{1}$, Paolo Vineis ${ }^{2}$, Giske Ursin ${ }^{1,4,5}$, Robert Lyle ${ }^{3,6}$, Trine B Rounge $e^{1,7}$

Affiliations:

1 Department of Research, Cancer Registry of Norway, Oslo, Norway

2 Department of Epidemiology and Biostatistics, Imperial College London, London, UK

3 Department of Medical Genetics, Oslo University Hospital and University of Oslo, Oslo, Norway

4 Department of Nutrition, Institute of Basic Medical Sciences, University of Oslo, Oslo, Norway.

5 University of Southern California, Los Angeles, CA, USA.

6 PharmaTox Strategic Research Initiative, School of Pharmacy, University of Oslo, Oslo, Norway

7 Department of Informatics, University of Oslo, Oslo, Norway

Corresponding author*

Hilde Langseth

Department of Research

Cancer Registry of Norway

Post box 5313 Majorstuen

0304 Oslo

Norway

E-mail: hilde.langseth@kreftregisteret.no

\begin{abstract}
There is justified optimism regarding the use of miRNAs as early detection biomarkers of cancer. They are well characterized and are involved in all the hallmarks of cancer. Less is

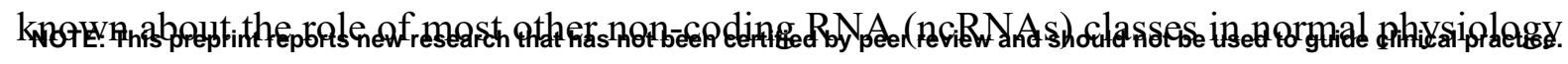


medRxiv preprint doi: https://doi.org/10.1101/2021.01.22.20243154; this version posted January 26, 2021. The copyright holder for this preprint (which was not certified by peer review) is the author/funder, who has granted medRxiv a license to display the preprint in All rights reserved. No reuse allowed without permission.

and tumorigenesis. The JanusRNA dataset consist of circulating RNA profiles of pre-clinical samples from 1631 cancer patients and 673 cancer-free controls. We studied eight cancer types including cancer of the: lung, colon, rectum, prostate, breast, testis, ovaries and gallbladder. JanusRNA has its origin from the large population-based Janus Serum Bank Cohort which consists of 318628 Norwegians. The dataset combines information from the complete nationwide cancer registry, RNA sequencing profiles from 1631 cancer patients and 673 cancer-free controls, as well as data on lifestyle, anthropometry and biochemical measurements from national health surveys. The Janus Serum Bank is specifically suited for studies of early detection and risk biomarkers of cancer, since samples are collected nationwide over a large time span, pre-clinically and cancer occurs at different points in time after blood draw. We used a nested case-control design, selecting both cases and controls among the Janus cohort members. We restricted our selection to cases with at least one sample collected within 10 years prior to cancer diagnosis. We selected 673 cancer-free Janus participants for comparison of RNA levels with the cancer cases. The controls were frequency matched to the case group on sex, age at blood donation and date of blood donation. The JanusRNA dataset has been used to investigate the natural variation of circulating RNAs in cancer-free individuals. This data resource was also used in a study of variation in RNA expression associated with common traits like age, sex, smoking, BMI and physical activity in cancer-free individuals. RNA dynamics in lung and testicular carcinogenesis throughout a 10year follow-up has also been studied.

\section{Data resource basics}

There is justified optimism regarding the use of miRNAs as early detection biomarkers of cancer. They are well characterized and are involved in all the hallmarks of cancer (1). Less is known about the role of most other non-coding RNA (ncRNAs) classes in normal physiology 
medRxiv preprint doi: https://doi.org/10.1101/2021.01.22.20243154; this version posted January 26, 2021. The copyright holder for this preprint (which was not certified by peer review) is the author/funder, who has granted medRxiv a license to display the preprint in All rights reserved. No reuse allowed without permission.

and tumorigenesis. Several classes of ncRNA act as regulators of key cellular processes, many of which are associated with cancer (2). Circulating ncRNAs may improve cancer management in the future as minimally invasive biomarkers. Large prospective cohorts with harmonized genetic and phenotypic data are required to realize the potential of ncRNAs as early cancer biomarkers, but such datasets are rare (3).

In this resource profile, we present the circulating RNA dataset available within the large prospective Janus Serum Bank Cohort in Norway (Janus RNA). The resource was established to facilitate research on RNA dynamics in samples collected up to 10 years prior to cancer diagnosis, compared to cancer-free controls, and with the long-term objective of identifying early detection biomarkers of cancer. The data resource will be instrumental for a wide range of national and international cancer research projects in the future.

We studied eight cancer types. Five of these cancer types are of major public health concern in many countries: lung cancer (LC), colon cancer (CC), rectum cancer (REC), prostate (PC) and breast cancer (BC). In all of them early detection screening biomarkers could have big public health implications. We included testicular germ cell tumors (TGCT), the most common malignancy in young males in most Western countries. Further, we expanded the dataset with cancer of the ovaries (OC) and gallbladder (GBC) which are diseases with poor prognosis since they are often diagnosed at advanced stages.

\section{Data collected}

JanusRNA has its origin in the large population-based Janus Serum Bank Cohort which consists of 318628 Norwegians. The serum bank is administered by the Cancer Registry of Norway (CRN) (4). The dataset combines information from the complete nationwide cancer registry (5), RNA sequencing profiles from 1631 cancer patients and 673 cancer-free controls, as well as data on lifestyle, anthropometry and biochemical measurements from national health surveys (6) (Figure 1). The Janus Serum Bank is 
medRxiv preprint doi: https://doi.org/10.1101/2021.01.22.20243154; this version posted January 26, 2021. The copyright holder for this preprint (which was not certified by peer review) is the author/funder, who has granted medRxiv a license to display the preprint in All rights reserved. No reuse allowed without permission.

specifically suited for studies of early detection and risk biomarkers, since samples were collected nationwide over a large time span, pre-clinically. Cancer has occurred at different points in time after the blood draw.

\section{Study design and Sampling strategy}

We used a nested case-control design, selecting both cases and controls among the Janus cohort members. This design offers logistic efficiency, is typically used for molecular epidemiological studies within prospective cohorts, and is suited for studying biomarkers that can be influenced by analytical batch, long-term storage and freeze-thaw cycles (7).

\section{Case selection}

The cases were identified by linking the Janus Cohort to the CRN using the individual's Norwegian national identity number. We included cohort participants with the selected cancer sites as their primary cancer diagnosis. No prior cancer diagnosis (except non-melanoma skin cancer) were allowed, and at least $500 \mu 1$ of serum had to be available. We restricted our selection to cases with at least one sample collected within 10 years prior to cancer diagnosis. The dynamics in RNA levels prior to a cancer diagnosis is sparsely described, however studies in Janus showed that most changes in RNA expression occurred close to a lung cancer diagnosis (8), and depend on staging (9). Based on our knowledge from using pre-diagnostic samples we considered 10 years prior to diagnosis as a reasonable timeframe for the study objectives. The average age of recruitment to the Janus cohort is 41 years. Because most cancers occur at older ages, most of the eligible cancer cases have a long lag-time between sampling and diagnosis. Therefore, we selected all available cases in the time window up to five years prior to diagnosis and a selection of eligible cases in the 5-10 years prior to diagnosis.

Distribution of case samples in the different pre-diagnostic time-windows are shown in Figure 2.

\section{Control selection}

Controls were selected according to a modified version of the incidence density sampling method for nested case-control studies (10). The cases were set up in strata based on age at 
medRxiv preprint doi: https://doi.org/10.1101/2021.01.22.20243154; this version posted January 26, 2021. The copyright holder for this preprint (which was not certified by peer review) is the author/funder, who has granted medRxiv a license to display the preprint in All rights reserved. No reuse allowed without permission.

blood sampling, gender, time period and county of residence at sampling. The date of diagnosis for the latest case in the case strata, was set as limit for all controls in the strata. The controls had to be alive and free from cancer at this date to be included in the control-pool. In addition, they had to be free from cancer up to ten year after blood collection. Due to the many unknown factors that affect the RNA levels prior to a cancer diagnosis, we considered it appropriate to set these additional criteria for the controls to give the best basis of comparisons between cases and controls. We then randomly selected frequency matched controls such that the case/control ratio was the same within each stratum (11).

We profiled circulating RNA by sequencing 2997 serum samples from 1631 cancer cases. This includes cancer of the lung $(n=404)$, colon $(n=308)$, rectum $(n=182)$, breast $(n=206)$, prostate $(n=332)$, testis $(n=84)$, gallbladder $(n=27)$ and ovaries $(n=88)$. Gender, age at blood donation and age at diagnosis by cancer type is shown in Table 1 . There are 199 cases with a second cancer diagnosis and 22 cases with a third cancer diagnosis. Furthermore, 107 of the controls developed a cancer diagnosis 10 years or more after the blood donation (not shown in table). Multiple samples (up to 7 time points) are available for a subset of the cancer patients, allowing investigation of temporal variations in samples from the same individual (Table 1). RNA profiles were also produced from 673 cancer-free control samples collected at a single time point. A pooled positive control sample, consisting of serum from several individuals, was profiled 28 times for quality and reproducibility assessment. In addition, for each batch of 96 samples, we included two negative control samples, one negative extraction control (NEC) and one water control from the library preparations.

\section{Data set production}

JanusRNA contains harmonized data from three sources: clinical cancer records from CRN, lifestyle information from nationwide health surveys, and RNA profiles and sampling information from Janus (Figure 1). 
medRxiv preprint doi: https://doi.org/10.1101/2021.01.22.20243154; this version posted January 26, 2021. The copyright holder for this preprint (which was not certified by peer review) is the author/funder, who has granted medRxiv a license to display the preprint in All rights reserved. No reuse allowed without permission.

\section{Cancer Registry data}

Since1952, CRN has systematically collected mandatory notifications on cancer occurrence for the Norwegian population. The registration is considered to be close to complete from 1953, with $98.8 \%$ completeness for the registration period 2001- 2005 (5). Information from clinical notifications, pathology reports and death certificates are the main sources that enables the CRN to code and store data on cancer patients in Norway. Information from the Norwegian Patient Registry (NPR) is an important additional source for identifying cancer cases. Clinical registries, also administered by CRN provide detailed information about diagnostic procedures, pathology-examinations, treatment and follow-up from cases that were diagnosed after 2004 (12).

\section{Health survey data on lifestyle, anthropometry and biochemical measurements}

Survey data were collected at the time of blood donation from most study participants (Table 2). The quality, completeness and standardization of these data has been described elsewhere (6). In brief, participants in the health surveys completed a baseline questionnaire about smoking habits and physical activity, and anthropometry and blood pressure were measured. Biochemical parameters such as cholesterol, triglycerides and glucose were also measured. As shown in (Table 2), the proportion of current smokers ranges from $23 \%$ in rectal cancer to $70 \%$ in lung cancer in males, and from $27 \%$ in breast cancer to $70 \%$ in lung cancer in females. The percentage of obese individuals $\left(\mathrm{BMI} \geq 30 \mathrm{~kg} / \mathrm{m}^{2}\right)$ ranges from $2 \%$ in testicular cancer cases to $14 \%$ in male colon cancer cases, in females BMI ranges from $8 \%$ in breast cancer cases to $20 \%$ in gallbladder cancer cases. Sedentary physical activity levels (inactive + low) varied from $43 \%$ in male gall bladder cases to $69 \%$ in male lung cancer cases. In women, $60 \%$ 
medRxiv preprint doi: https://doi.org/10.1101/2021.01.22.20243154; this version posted January 26, 2021. The copyright holder for this preprint (which was not certified by peer review) is the author/funder, who has granted medRxiv a license to display the preprint in All rights reserved. No reuse allowed without permission.

of the breast cancer cases and $87 \%$ of the ovarian cancer cases reported sedentary physical activity habits.

\section{Sequencing data production}

We have developed a platform for small RNA sequencing, tailored to low RNA yield samples such as archived serum samples. This platform enables expression profiling of RNAs from 17-47 nucleotides, annotation of 9 RNA classes and sequence isoform identification. The quality and quantity of RNA was sufficient for analyses, independent of storage time and sample pre-processing (13). Sequencing data production entails three steps:

Step $1-R N A$ isolation: RNA was extracted from $2 \times 200 \mu 1$ serum using the miRNeasy Serum/Plasma kit (Cat. no 1071073, Qiagen) on a QIAcube (Qiagen). Internal spike-in control C. elegans miR-39 was added to each sample. Glycogen (Cat. no AM9510, Invitrogen) was used as carrier during the RNA extraction step. The eluate was concentrated using Ampure beads XP (Agencourt). Cases and controls were blinded.

Step 2 - Library preparation: Small RNAseq libraries were created using NEBNext ${ }^{\circledR}$ Small RNA Library Prep Set for Illumina (Cat. No E7300, New England Biolabs Inc.) with a cut size on the Pippin Prep (Cat. No CSD3010, Sage Science) of 17-47 nucleotides.

Step 3 - RNA sequencing: 12 samples were sequenced per lane on an Illumina HiSeq 2500 platform to an average depth of 18 million reads per sample. A detailed description of the RNA profiles is available (14).

\section{Bioinformatics pipeline}

A custom RNA analysis pipeline for processing raw RNA sequences to count data and expression profiles has been established (Figure 3). It includes adaptor and low-quality data filtering, mapping, and counting of RNA annotations . The RNAseq reads were initially trimmed for adapters using AdapterRemoval (v2.1.7) (15). We then mapped the collapsed reads (generated by FASTX v0.14) to the human genome (hg38) using Bowtie2 (10 
medRxiv preprint doi: https://doi.org/10.1101/2021.01.22.20243154; this version posted January $26,2021$. The copyright holder for this preprint (which was not certified by peer review) is the author/funder, who has granted medRxiv a license to display the preprint in All rights reserved. No reuse allowed without permission.

alignments per read were allowed). All multi-mapped reads with equivalent mapping score were counted. We compiled a comprehensive annotation set from miRBase (v21) (16) for miRNAs, pirBAse (v1.0) for piRNAs63, GENCODE (v26) (17) for other RNAs and tRNAs. We used SeqBuster (v3.1) (18) to profile isomiR and miRNA profiles. To count the mapped reads, HTSeq (v0.7.2) (19) was used. Candidate tRNA fragments (tRFs) were selected from reads mapped to tRNA annotations. We later updated our workflow and tRFs were profiled using MINTmap tool (https://www.nature.com/articles/srep41184). When reporting the identified RNAs, we excluded RNAs with fewer than 10 reads in more than $20 \%$ of the samples (20).

The average sequencing depth and average number of RNAs by cancer type is given in Figure 4A and Figure 4B. The most abundant RNA type across all cancer types and controls is mRNA followed by isomiRs. The heat-map in figure $4 \mathrm{~B}$ shows the average number of identified RNAs for the different cancer types. The RNAseq read counts in millions for all RNA classes combined, ranged from 13.5 in ovarian cancer patients to 20.7 in female gallbladder patients, and standard deviations ranged between 2.9 and 6.2 (Supplementary Table 1).

\section{Ethical approval}

The JanusRNA study was approved by the regional committee for medical and health research ethics, Oslo, Norway (2016/1290) and (2013/1821), and is based on a broad consent from participants in the Janus cohort. The JanusRNA database contains pseudonymized data.

\section{Funding}

The project was funded by the Research Council of Norway under the Program: 'Human Biobanks and Health data' project numbers: 229621/H10 and 24879/H10 (production of sequencing data from cases with cancer of the lung, colon, rectum, breast, prostate, ovaries and the main part of controls). Sequencing costs for the testicular cancer cases and a small 
medRxiv preprint doi: https://doi.org/10.1101/2021.01.22.20243154; this version posted January 26, 2021. The copyright holder for this preprint (which was not certified by peer review) is the author/funder, who has granted medRxiv a license to display the preprint in All rights reserved. No reuse allowed without permission.

number extra controls were covered by the Norwegian Cancer Society (grant number 1901572017) and sequencing costs for the gallbladder cases were supported by the European Union within the initiative "Biobanking and Biomolecular Research Infrastructure-Large Prospective Cohorts" (Collaborative study "Identification of biomarkers for gallbladder cancer risk prediction - Towards personalized prevention of an orphan disease") under grant agreement no. 313010 (BBMRI-LPC) and the German Federal Ministry of Education and Research (BMBF, grant 01DN15021).

\section{Data resource use}

The JanusRNA dataset has been used to investigate the natural variation of circulating RNAs in healthy controls (14). The core serum RNA repertoire in the cancer-free control group includes 258 micro RNAs (miRNA), 441 piwi-interacting RNAs (piRNA), 411 transfer RNAs (tRNA), 24 small nucleolar RNAs (snoRNA), 125 small nuclear RNAs (snRNA) and 123 miscellaneous RNAs (misc-RNA). We investigated biological and technical variation in expression, and the results suggest that many RNA molecules identified in serum shows signs of inter-individual variation (14). The same dataset was used to investigate the association between circulating RNAs and common traits such as age, sex, smoking, BMI and physical activity. The study showed that common traits influence circulating RNA expression, in particular age and sex, and concluded that these traits should be treated as potential confounders for RNA analyses (20). RNA dynamics in lung and testicular carcinogenesis throughout a 10 -year follow-up has been studied $(9,21)$. Ongoing studies include prediagnostic RNA dynamics in cancer of the lung, colorectal, prostate, breast, gallbladder, testis, ovary and a pan-cancer profile (https://www.kreftregisteret.no/en/Research/Projects/Small-non-coding-RNA-as-earlydetection-cancer-biomarkers/). 
medRxiv preprint doi: https://doi.org/10.1101/2021.01.22.20243154; this version posted January 26, 2021. The copyright holder for this preprint (which was not certified by peer review) is the author/funder, who has granted medRxiv a license to display the preprint in All rights reserved. No reuse allowed without permission.

\section{Strengths and weaknesses}

A strength of JanusRNA is the large number of population-based samples sequenced from eight different cancer types combined with high-quality cancer registry data and access to information on life-style factors at baseline such as BMI, smoking and physical activity, that may influence circulating RNA expression levels significantly. The selection of cases and controls is based on established procedures for linking biobank and registry data (22). We have created a robust and unique dataset to investigate RNA dynamics and biomarker potential across cancer types. It is also a strength that we have sequenced samples from a large cancer-free control group enabling us to study the variation in a healthy population. The control group gives the opportunity to explore disease versus trait-specific patterns, which is important for early detection biomarkers discovery. The control group profiles can be re-used to contrast compatible RNA profiles from a range of clinical studies. Another strength of the JanusRNA dataset is the pre-diagnostic sample collection, which provides the possibility of studying RNA levels prior to diagnosis and compare this with the healthy control group. We also use well-established sequencing platforms, biocomputational capacity and the RNA yield of our biobanked material as documented $(13,14,20,23)$. The sequencing read-depth is high (on average 18 million reads per sample), and targeting RNAs of 17-47 nucleotides enables comprehensive assessment of the major RNA classes.

There are some limitations to JanusRNA. First, we only have serial samples from approximately $30 \%$ of the participants, so the statistical power for investigating temporal changes in cancer specific analyses is low. Also, for the control subjects there is only one sample time point available with no opportunity to measure the changes in natural variation over time. Another limitation of the dataset is that detailed clinical information from clinical registries is available only for a subset of the cases with cancer of the breast (hormone receptor status), prostate (PSA and Gleason score), lung and rectum. Pathology reports can be 
medRxiv preprint doi: https://doi.org/10.1101/2021.01.22.20243154; this version posted January 26, 2021. The copyright holder for this preprint (which was not certified by peer review) is the author/funder, who has granted medRxiv a license to display the preprint in All rights reserved. No reuse allowed without permission.

reviewed to complete this information (24), however that is a time-consuming process.

Further, we are also missing survey data from approximately $13 \%$ of the study participants. Another weakness is the technical noise arising from analysing archived serum samples with low amounts of RNA. However, we have characterised the technical and biological variability and since technical variability is random, it has little impact on association studies.

\section{Reason to be cautious (limitations including generalisability)}

All RNA studies, including this one, may have problems with annotation and the lack of functional information that makes the interpretation of findings challenging. Trusted annotations are essential to correctly identify transcripts, yet well-known annotation databases are not optimal $(14,25)$. For example, piRNA annotations contain fragments corresponding to other RNAs (26) something that might reduce comparability between trait associations. For reuse of our dataset one has to be aware of some observed batch effects correlating with changes in kit lot numbers.

\section{Data resource access and collaborations}

The JanusRNA datasets generated for this article are not readily available because of the principles and conditions set out in articles $6(1)(\mathrm{e})$ and 9 (2) (j) of the General Data Protection Regulation (GDPR). National legal basis as per the Regulations on populationbased health surveys and ethical approval from the Norwegian Regional Committee for Medical and Health Research Ethics (REC) is also required.

There is work in progress to develop data sharing mechanisms in compliance with GDPR (27-29). In the meantime, we welcome ideas and proposals for potential collaborations for using the dataset. To facilitate this process, interested researchers can contact miRJanus@kreftregisteret.no 
medRxiv preprint doi: https://doi.org/10.1101/2021.01.22.20243154; this version posted January 26, 2021. The copyright holder for this preprint (which was not certified by peer review) is the author/funder, who has granted medRxiv a license to display the preprint in All rights reserved. perpetuity.

\section{Acknowledgements}

The sequencing service was provided by the Norwegian Sequencing Centre

$\underline{\text { www.sequencing.uio.no, a national technology platform hosted by Oslo University Hospital }}$ and the University of Oslo supported by the Research Council of Norway and the Southeastern Regional Health Authority. We acknowledge Dr Tom Grotmol at the CRN Department of Research and Prof Justo Lorenzo Bermejo Statistical Genetics Group, Institute of Medical Biometry \& Informatics, University of Heidelberg in Germany for close collaboration and production of the testicular and gallbladder datasets, respectively. We also thank senior lawyer Hilde Olav at the CRN for help with all legal issues related to data sharing. We are thankful to the Norwegian Cancer Society for providing funding for the Janus Serum Bank management through the years of cohort recruitment. The study used data from the Cancer Registry of Norway and the Norwegian Institute of Public Health. The interpretation and reporting of these data are the sole responsibility of the authors, and no endorsement by the Cancer Registry of Norway or the Norwegian Institute of Public Health is intended nor should be inferred.

\section{References}

1. Pichler M, Calin GA. MicroRNAs in cancer: from developmental genes in worms to their clinical application in patients. British journal of cancer. 2015;113(4):569-73.

2. Martens-Uzunova ES, Olvedy M, Jenster G. Beyond microRNA--novel RNAs derived from small non-coding RNA and their implication in cancer. Cancer Lett. 2013;340(2):201-11.

3. Njolstad PR, Andreassen OA, Brunak S, Borglum AD, Dillner J, Esko T, et al. Roadmap for a precision-medicine initiative in the Nordic region. Nat Genet. 2019;51(6):924-30.

4. Langseth H, Gislefoss RE, Martinsen JI, Dillner J, Ursin G. Cohort Profile: The Janus Serum Bank Cohort in Norway. International journal of epidemiology. 2017;46(2):403-4g.

5. Larsen IK, Smastuen M, Johannesen TB, Langmark F, Parkin DM, Bray F, et al. Data quality at the Cancer Registry of Norway: an overview of comparability, completeness, validity and timeliness. European journal of cancer (Oxford, England : 1990). 2009;45(7):1218-31.

6. Hjerkind KV, Gislefoss RE, Tretli S, Nystad W, Bjorge T, Engeland A, et al. Cohort Profile Update: The Janus Serum Bank Cohort in Norway. International journal of epidemiology. 2017;46(4):1101-2f.

7. Rundle AG, Vineis P, Ahsan H. Design options for molecular epidemiology research within cohort studies. Cancer epidemiology, biomarkers \& prevention : a publication of the American Association for Cancer Research, cosponsored by the American Society of Preventive Oncology. 2005;14(8):1899-907. 
medRxiv preprint doi: https://doi.org/10.1101/2021.01.22.20243154; this version posted January 26, 2021. The copyright holder for this preprint (which was not certified by peer review) is the author/funder, who has granted medRxiv a license to display the preprint in

8. Keller A, Leidinger P, Gislefoss R, Haugen A, Langseth H, Staehler P, et al. Stable serum miRNA profiles as potential tool for non-invasive lung cancer diagnosis. RNA biology. 2011;8(3):506-16.

9. Umu SU, Langseth H, Keller A, Meese E, Helland A, Lyle R, et al. A 10-year prediagnostic follow-up study shows that serum RNA signals are highly dynamic in lung carcinogenesis. Molecular oncology. 2020;14(2):235-47.

10. Richardson DB. An incidence density sampling program for nested case-control analyses. Occup Environ Med. 2004;61(12):e59.

11. Gail MH, Pfeiffer RM. On criteria for evaluating models of absolute risk. Biostatistics. 2005;6(2):227-39.

12. Cancer Registry of Norway. Cancer in Norway 2018 - Cancer incidence, mortality, survival and prevalence in Norway. . Oslo: Cancer Registry of Norway, 2019.

13. Rounge TB, Lauritzen M, Langseth H, Enerly E, Lyle R, Gislefoss RE. microRNA Biomarker Discovery and High-Throughput DNA Sequencing Are Possible Using Long-term Archived Serum Samples. Cancer epidemiology, biomarkers \& prevention : a publication of the American Association for Cancer Research, cosponsored by the American Society of Preventive Oncology. 2015;24(9):13817.

14. Umu SU, Langseth H, Bucher-Johannessen C, Fromm B, Keller A, Meese E, et al. A comprehensive profile of circulating RNAs in human serum. RNA biology. 2018;15(2):242-50.

15. Schubert M, Lindgreen S, Orlando L. AdapterRemoval v2: rapid adapter trimming, identification, and read merging. BMC research notes. 2016;9:88.

16. Kozomara A, Griffiths-Jones S. miRBase: annotating high confidence microRNAs using deep sequencing data. Nucleic acids research. 2014;42(Database issue):D68-73.

17. Harrow J, Frankish A, Gonzalez JM, Tapanari E, Diekhans M, Kokocinski F, et al. GENCODE: the reference human genome annotation for The ENCODE Project. Genome research. 2012;22(9):1760-74.

18. Pantano L, Estivill X, Marti E. SeqBuster, a bioinformatic tool for the processing and analysis of small RNAs datasets, reveals ubiquitous miRNA modifications in human embryonic cells. Nucleic acids research. 2010;38(5):e34.

19. Anders S, Pyl PT, Huber W. HTSeq--a Python framework to work with high-throughput sequencing data. Bioinformatics (Oxford, England). 2015;31(2):166-9.

20. Rounge TB, Umu SU, Keller A, Meese E, Ursin G, Tretli S, et al. Circulating small noncoding RNAs associated with age, sex, smoking, body mass and physical activity. Scientific reports. 2018;8(1):17650.

21. Burton J, Umu SU, Langseth H, Grotmol T, Grimsrud TK, Haugen TB, et al. Serum RNA Profiling in the 10-Years Period Prior to Diagnosis of Testicular Germ Cell Tumor. Frontiers in oncology. 2020;10:574977.

22. Langseth H, Luostarinen T, Bray F, Dillner J. Ensuring quality in studies linking cancer registries and biobanks. Acta Oncol. 2010;49(3):368-77.

23. Keller A, Rounge T, Backes C, Ludwig N, Gislefoss R, Leidinger P, et al. Sources to variability in circulating human miRNA signatures. RNA biology. 2017;14(12):1791-8.

24. Johansson ALV, Trewin CB, Hjerkind KV, Ellingjord-Dale M, Johannesen TB, Ursin G. Breast cancer-specific survival by clinical subtype after 7 years follow-up of young and elderly women in a nationwide cohort. Int J Cancer. 2019;144(6):1251-61.

25. Fromm B, Billipp T, Peck LE, Johansen M, Tarver JE, King BL, et al. A Uniform System for the Annotation of Vertebrate microRNA Genes and the Evolution of the Human microRNAome. Annu Rev Genet. 2015;49:213-42.

26. Tosar JP, Rovira C, Cayota A. Non-coding RNA fragments account for the majority of annotated piRNAs expressed in somatic non-gonadal tissues. Commun Biol. 2018;1:2.

27. Bentzen HB, Hostmaelingen N. Balancing Protection and Free Movement of Personal Data: The New European Union General Data Protection Regulation. Annals of internal medicine. 2019.

28. Ursin G, Malila N, Chang-Claude J, Gunter M, Kaaks R, Kampman E, et al. Sharing data safely while preserving privacy. The Lancet. 2019;394.

29. Ursin G, Stenbeck M, Chang-Claude J, Gunter M, Kaaks R, Kampman E, et al. Data must be shared—also with researchers outside of Europe. The Lancet. 2019;394. 
medRxiv preprint doi: https://doi.org/10.1101/2021.01.22.20243154; this version posted January 26, 2021. The copyright holder for this preprint (which was not certified by peer review) is the author/funder, who has granted medRxiv a license to display the preprint in All rights reserved. No reuse allowed without permission. 
medRxiv preprint doi: https://doi.org/10.1101/2021.01.22.20243154; this version posted January $26,2021$. The copyright holder for this preprint (which was not certified by peer review) is the author/funder, who has granted medRxiv a license to display the preprint in

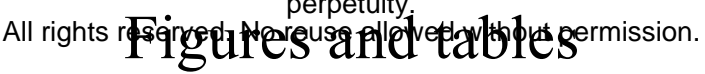

Cancer Registry of Norway
From the incidence register
- date of diagnosis
- topography
- morphology
- basis of diagnosis
- staging (localized, regional,
distant/metastasis)
- data of death from cancer
From quality registers for breast and
prostate cancer
- treatment data
- breast (surgery, radiation, chemo)
- prostate (surgery)

\section{Janus Serum Bank Cohort}

- date at blood donations

- information on pre-analytical

sample handling

- county of residence at blood

donation

- sample processing procedures

- RNA sequencing

isomiR, tRF, InCRNA, miRNA,

mRNA, piRNA, SNORNA, SNRNA,

tRNA

- prostate (surgery)
Health examination Surveys

Questionnaire dato

- smoking

- physical activity level

- diet

Anthropometric and biochemical

measurements

- hight

- weight

- body mass index

- blood pressure

- non-fasting serum total

cholesterol and triglyceride

\section{Janus RNA dataset}

Figure 1. Study population and data sources. 
medRxiv preprint doi: https://doi.org/10.1101/2021.01.22.20243154; this version posted January $26,2021$. The copyright holder for this preprint (which was not certified by peer review) is the author/funder, who has granted medRxiv a license to display the preprint in All rights reserved. No reuse allowed without permission.

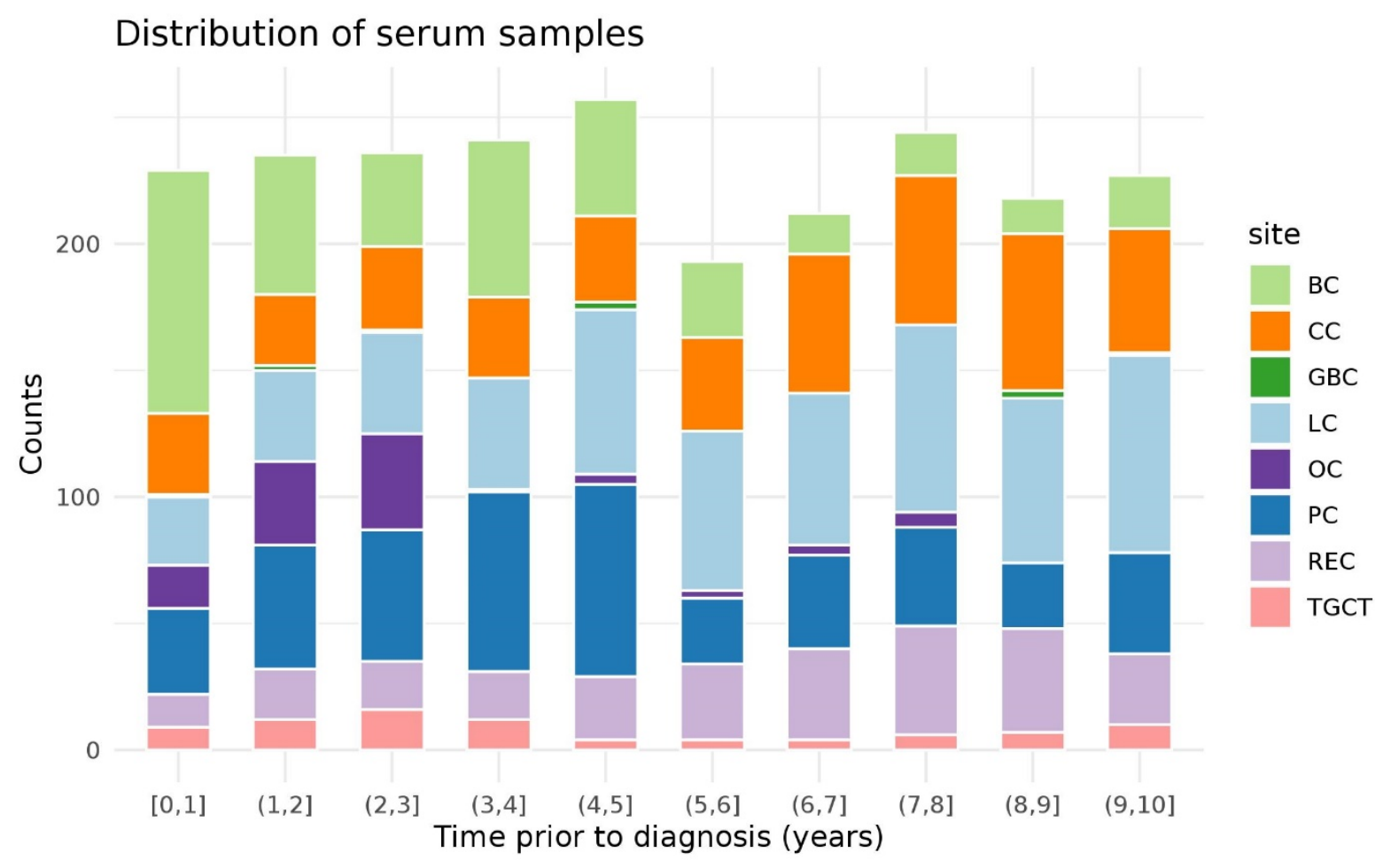

Figure 2. Sample distribution by pre-diagnostic collection timepoints. One year time window from 0 to 10 years prior to diagnosis on the $\mathrm{x}$-axis and number of samples by cancer type on the y-axis. 
medRxiv preprint doi: https://doi.org/10.1101/2021.01.22.20243154; this version posted January $26,2021$. The copyright holder for this preprint (which was not certified by peer review) is the author/funder, who has granted medRxiv a license to display the preprint in

All rights reserved. No reuse allowed without permission.

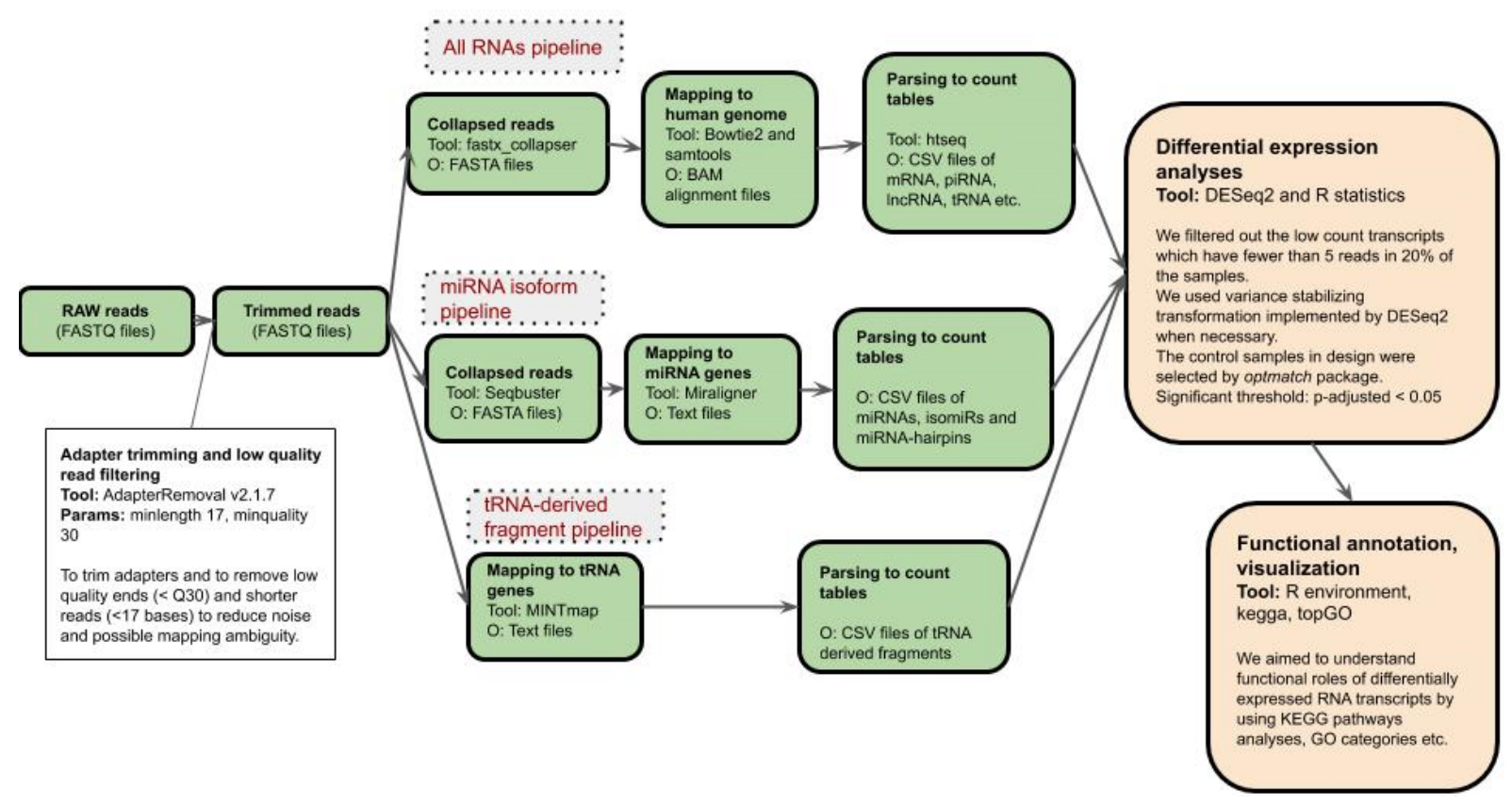

Figure 3. Illustration of the bioinformatic pipeline for all RNA classes identified in

JanusRNA, including adaptor and low-quality data clean-up, mapping to the genome, and counting all RNAs between 17 and 47 nucleotides in length. 
medRxiv preprint doi: https://doi.org/10.1101/2021.01.22.20243154; this version posted January 26, 2021. The copyright holder for this preprint (which was not certified by peer review) is the author/funder, who has granted medRxiv a license to display the preprint in

All rights reserved. No reuse allowed without permission.

\section{A Read depths of samples}

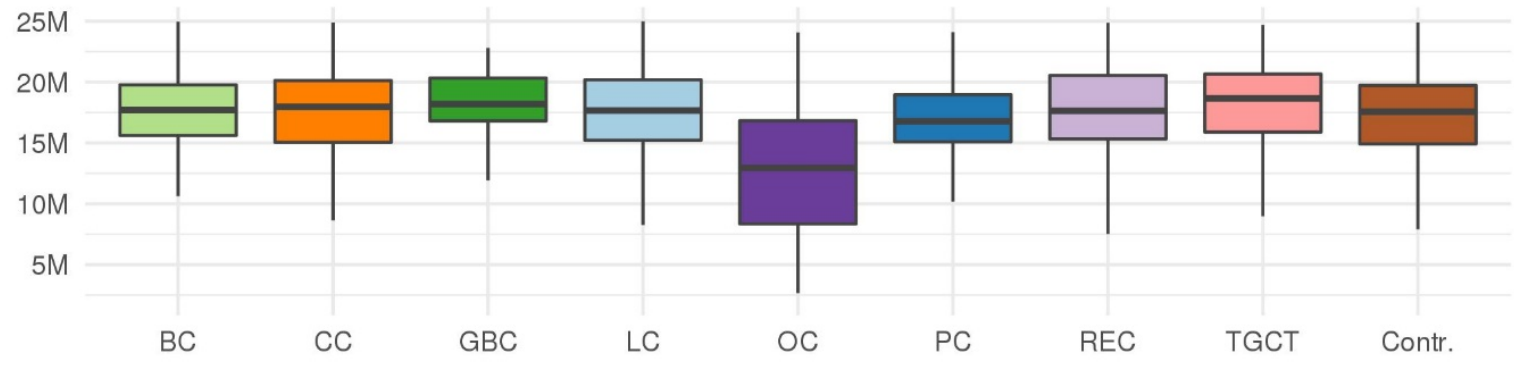

\section{B Average number of identified RNAs}

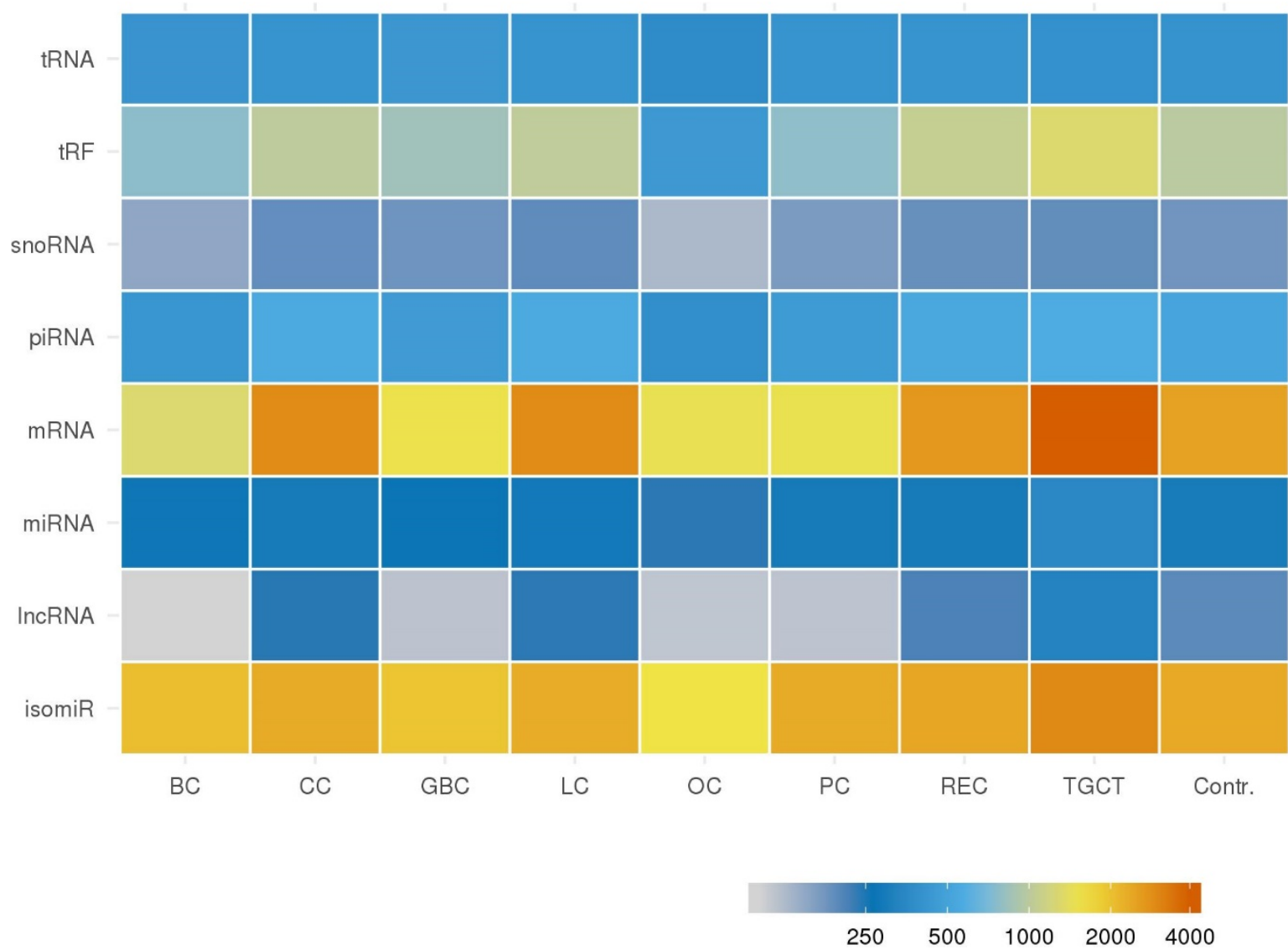

Figure 4. A) The average sequencing depth range from 13.5 mill reads in the pre-diagnostic samples from ovarian cancer patients (OC) to 21 mill reads in gall bladder cancer patients (GBC). B) The heat-map shows the average number of identified RNAs by cancer type. The most highly expressed RNAs are indicated by red color and the lowest expressed by gray color. 


\begin{tabular}{|c|c|c|c|c|c|c|c|c|c|c|c|c|c|c|c|c|}
\hline \multirow[b]{2}{*}{ Cancer site ICD 10} & \multicolumn{8}{|c|}{ Men $(n=1379)$} & \multicolumn{8}{|c|}{ Women $(n=925)$} \\
\hline & $\begin{array}{c}\text { Lung } \\
\text { (C33-34) }\end{array}$ & $\begin{array}{l}\text { Colon } \\
\text { (C18) }\end{array}$ & $\begin{array}{l}\text { Rectum } \\
\text { (C19-20) }\end{array}$ & $\begin{array}{c}\text { Gall } \\
\text { bladder } \\
\text { (C23) }\end{array}$ & $\begin{array}{l}\text { Prostate } \\
\text { (C61) }\end{array}$ & $\begin{array}{l}\text { Testis } \\
\text { (C62) }\end{array}$ & $\begin{array}{c}\text { Contr } \\
-\end{array}$ & TOT & $\begin{array}{c}\text { Lung } \\
\text { (C33-34) }\end{array}$ & $\begin{array}{l}\text { Colon } \\
(\mathrm{C} 18)\end{array}$ & $\begin{array}{l}\text { Rectum } \\
\text { (C19-20) }\end{array}$ & $\begin{array}{c}\text { Gall } \\
\text { bladder } \\
\text { (C23) }\end{array}$ & $\begin{array}{l}\text { Breast } \\
\text { (C50) }\end{array}$ & $\begin{array}{l}\text { Ovary } \\
\text { (C56) }\end{array}$ & $\begin{array}{c}\text { Contr } \\
-\end{array}$ & TOT \\
\hline No of individuals & 274 & 162 & 118 & 7 & 332 & 84 & 402 & 1379 & 130 & 146 & 64 & 20 & 206 & 88 & 271 & 925 \\
\hline Age at recruitment & $54(8.61)$ & $53.1(9.5)$ & $52.9(8.19)$ & $44.1(3.28)$ & $59.9(8.67)$ & $34.8(6.46)$ & $50.7(12)$ & - & $53.4(8.5)$ & $53.2(9.92)$ & $51.2(8.53)$ & $47.3(8.87)$ & $45.5(6.97)$ & $46.7(8.57)$ & $48.5(10.2)$ & - \\
\hline Age at diagnosis, mean (SD) & $60.2(8.58)$ & $59(9.19)$ & $59.3(8.09)$ & $53.4(3.15)$ & $64.5(7.99)$ & $38.6(5.07)$ & $74(9.12)$ & - & $59.3(8.13)$ & $59.2(9.64)$ & $57.7(8.62)$ & $56.4(10)$ & $49.3(7.68)$ & $48.8(8.60)$ & $70.8(8.29)$ & - \\
\hline Total \# of samples & 382 & 231 & 183 & 7 & 450 & 84 & 405 & 1742 & 177 & 193 & 93 & 20 & 395 & 106 & 271 & 1255 \\
\hline No with 1 sample & 270 & 162 & 118 & 7 & 331 & 84 & 402 & 1374 & 130 & 144 & 64 & 20 & 206 & 88 & 271 & 923 \\
\hline No with 2 samples & 77 & 46 & 41 & 0 & 68 & 0 & 3 & 235 & 40 & 42 & 24 & 0 & 132 & 14 & 0 & 252 \\
\hline No with $\leq 3$ samples & 35 & 23 & 24 & 0 & 51 & 0 & 0 & 133 & 7 & 7 & 5 & 0 & 57 & 4 & 0 & 80 \\
\hline
\end{tabular}

Table 1. Basic characteristics of the study subjects and samples included in the JanusRNA dataset, by gender. 


\begin{tabular}{|c|c|c|c|c|c|c|c|c|c|c|c|c|c|c|}
\hline \multicolumn{8}{|c|}{ Men $(n=1376)$} & \multicolumn{6}{|c|}{ Women $(\mathrm{n}=934)$} & \multirow[b]{2}{*}{$\begin{array}{c}\text { Contr } \\
-\end{array}$} \\
\hline Cancer site ICD 10 & $\begin{array}{c}\text { Lung } \\
\text { (C33-34) }\end{array}$ & $\begin{array}{l}\text { Colon } \\
\text { (C18) }\end{array}$ & $\begin{array}{l}\text { Rectum } \\
\text { (C19-20) }\end{array}$ & $\begin{array}{c}\text { Gall } \\
\text { bladder } \\
(\mathrm{C} 23) \\
\end{array}$ & $\begin{array}{l}\text { Prostate } \\
\text { (C61) }\end{array}$ & $\begin{array}{l}\text { Testis } \\
\text { (C62) }\end{array}$ & $\begin{array}{c}\text { Contr } \\
-\end{array}$ & $\begin{array}{c}\text { Lung } \\
\text { (C33-34) }\end{array}$ & $\begin{array}{l}\text { Colon } \\
\text { (C18) }\end{array}$ & $\begin{array}{l}\text { Rectum } \\
\text { (C19-20) }\end{array}$ & $\begin{array}{c}\text { Gall } \\
\text { bladder } \\
(\mathrm{C} 23) \\
\end{array}$ & $\begin{array}{l}\text { Breast } \\
\text { (C50) }\end{array}$ & $\begin{array}{l}\text { Ovary } \\
\text { (C56) }\end{array}$ & \\
\hline Smoking n (\%) & $239(87)$ & $135(83)$ & $88(75)$ & $7(100)$ & $265(80)$ & $63(75)$ & $287(72)$ & $114(88)$ & $131(90)$ & $57(89)$ & $20(100)$ & $141(68)$ & $88(94)$ & $183(68)$ \\
\hline Current & $191(70)$ & $45(28)$ & $27(23)$ & $3(43)$ & $91(27)$ & $25(29)$ & $105(26)$ & $91(70)$ & $53(36)$ & $20(31)$ & $6(30)$ & $55(27)$ & $33(37)$ & $67(25)$ \\
\hline Former & $46(16)$ & $61(37)$ & $44(38)$ & $3(43)$ & $118(36)$ & $19(23)$ & $108(27)$ & $20(16)$ & $33(23)$ & $6(9)$ & $4(20)$ & $24(12)$ & $15(17)$ & $39(14)$ \\
\hline Never & $2(1)$ & $29(18)$ & $17(14)$ & $1(14)$ & $56(17)$ & $19(23)$ & $77(19)$ & $3(2)$ & $45(31)$ & $31(49)$ & $10(50)$ & $62(30)$ & $35(40)$ & $77(29)$ \\
\hline Missing & $35(13)$ & $27(17)$ & $30(25)$ & $0(0)$ & $67(20)$ & $21(25)$ & $112(28)$ & $16(12)$ & $15(10)$ & $7(11)$ & $0(0)$ & $65(31)$ & $5(6)$ & $88(32)$ \\
\hline Body mass index (mean and SD) & $25.1(3.59)$ & $26.4(3.63)$ & $26.3(3.52)$ & $24.6(1.63)$ & $26.3(3.55)$ & $25.2(3.52)$ & $25.1(2.9)$ & $25.2(4.96)$ & $25.9(4.57)$ & $25.8(4.51)$ & $26.8(5.47)$ & $24.7(4.34)$ & $24.4(3.75)$ & $24.9(3.75)$ \\
\hline Body mass index n (\%) & $239(87)$ & $135(83)$ & $88(75)$ & $7(100)$ & $265(80)$ & $62(74)$ & 72 & $114(88)$ & $130(89)$ & $57(89)$ & $20(100)$ & $142(69)$ & $84(95)$ & $183(68)$ \\
\hline Underweight & $6(2)$ & $1(1)$ & $1(1)$ & $0(0)$ & $3(1)$ & $0(0)$ & $1(0.2)$ & $3(2)$ & $1(1)$ & $3(5)$ & $0(0)$ & $0(0)$ & $3(3)$ & $4(1)$ \\
\hline Normal & $113(41)$ & $51(31)$ & $35(30)$ & $4(57)$ & $99(30)$ & $29(35)$ & $135(33)$ & $62(48)$ & $66(45)$ & $27(42)$ & $11(55)$ & $93(45)$ & $48(55)$ & $86(32)$ \\
\hline Overweight & $102(37)$ & $61(38)$ & $37(31)$ & $3(43)$ & $124(37)$ & $31(37)$ & $132(33)$ & $29(22)$ & $37(25)$ & $20(31)$ & $5(25)$ & $34(16)$ & $25(28)$ & $68(25)$ \\
\hline Obese & $18(7)$ & $22(14)$ & $15(13)$ & $0(0)$ & $39(12)$ & $2(2)$ & $23(6)$ & $20(16)$ & $26(18)$ & $7(11)$ & $4(20)$ & $15(8)$ & $8(9)$ & $26(10)$ \\
\hline Missing & $35(13)$ & $27(17)$ & $30(25)$ & $0(0)$ & $67(20)$ & $22(26)$ & $111(28)$ & $16(12)$ & $16(11)$ & $7(11)$ & $0(0)$ & $64(31)$ & $4(5)$ & $87(32)$ \\
\hline Physical activity n (\%) & $239(87)$ & $133(82)$ & $88(75)$ & $7(100)$ & $257(77)$ & $63(75)$ & $286(71)$ & $114(88)$ & $130(89)$ & $57(89)$ & $19(95)$ & $141(68)$ & $84(95)$ & $181(67)$ \\
\hline inactive & $66(24)$ & $22(14)$ & $24(20)$ & $2(29)$ & $38(11)$ & $16(19)$ & $41(10)$ & $26(20)$ & $25(17)$ & $11(17)$ & $6(30)$ & $28(13)$ & $20(22)$ & $27(10)$ \\
\hline low & $122(45)$ & $81(50)$ & $47(40)$ & $1(14)$ & $168(51)$ & $32(38)$ & $176(44)$ & $80(62)$ & $94(64)$ & $40(63)$ & $11(55)$ & $97(47)$ & $57(65)$ & $138(51)$ \\
\hline medium & $49(17)$ & $28(17)$ & $13(11)$ & $4(57)$ & $51(15)$ & $14(17)$ & $67(17)$ & $8(6)$ & $10(7)$ & $6(9)$ & $2(10)$ & $16(8)$ & $6(7)$ & $14(5)$ \\
\hline high & $2(1)$ & $2(1)$ & $4(4)$ & $0(0)$ & $0(0)$ & $1(1)$ & $2(0.5)$ & $0(0)$ & $1(1)$ & $0(0)$ & $0(0)$ & $0(0)$ & $1(1)$ & $2(1)$ \\
\hline Missing & $35(13)$ & $29(18)$ & $30(25)$ & $0(0)$ & $75(23)$ & $21(25)$ & $116(29)$ & $16(12)$ & $16(11)$ & $7(11)$ & $1(5)$ & $65(32)$ & $4(5)$ & $90(33)$ \\
\hline Total cholesterol, mean (SD) & $6.27(1.26)$ & $6.32(1.05)$ & $6.47(1.26)$ & $5.69(1.29)$ & $6.13(1.17)$ & $5.71(1.10)$ & $6.24(1.14)$ & $6.65(1.36)$ & $6.62(1.27)$ & $6.85(1.37)$ & $6.04(0.82)$ & $5.86(1.15)$ & $6.27(1.56)$ & $6.27(1.33)$ \\
\hline Triglycerides, mean (SD) & $2.14(1.99)$ & $2.21(1.31)$ & $2.35(1.86)$ & $2.43(1.29)$ & $2.06(1.26)$ & $1.75(0.98)$ & $2.15(1.26)$ & $1.73(0.89)$ & $1.71(1.43)$ & $1.91(1.14)$ & $1.54(0.80)$ & $1.33(0.77)$ & $1.40(0.73)$ & $1.47(0.73)$ \\
\hline Glucose, mean (SD) & $5.97(1.42)$ & $5.67(1.06)$ & $5.82(1.18)$ & $6.16(0.59)$ & $5.72(1.11)$ & $5.27(0.81)$ & $5.88(1.71)$ & $6.07(1.82)$ & $5.78(1.3)$ & $5.75(0.91)$ & $5.64(0.60)$ & $5.81(0.91)$ & $5.51(0.69)$ & $5.75(1.09)$ \\
\hline
\end{tabular}

Table 2. Selected health survey data for the JanusRNA participants 